\title{
Detection of Mycoplasma agalactiae by Polymerase Chain Reaction in Jordanian Sheep and Goat Herds
}

\author{
D. ZENDULKOVÁ, A. MADANAT, P. LÁNY, K. ROSENBERGOVÁ, Z. POSPÍŠIL
}

Department of Infectious Diseases and Veterinary Epidemiology, University of Veterinary and Pharmaceutical Sciences Brno, Czech Republic

Received March 23, 2006

Accepted November 29, 2006

\begin{abstract}
Zendulková D., A. Madanat, P. Lány, K. Rosenbergová, Z. Pospíši,: Detection of Mycoplasma agalactiae by Polymerase Chain Reaction in Jordanian Sheep and Goat Herds. Acta Vet Brno 0000, 00: 71-77

The aim of the study was to ascertain whether sheep and goats from selected Jordanian herds were infected with Mycoplasma agalactiae, the most common aetiological agent of contagious agalactia of sheep and goats. All examined animals showed clinical signs of disease at the time of sample collection. The group included 35 animals, 15 sheep and 20 goats. For microbiological examination, a total of 107 swabs were taken from conjunctival, nasal, vaginal or preputial mucosae and from the external auditory canal. Identification of the species isolated was carried out by a polymerase chain reaction. Of the 35 animals, 21 (4 sheep and 17 goats) tested positive for Mycoplasma agalactiae. These results confirmed our assumption that this mycoplasma species is present in Jordanian herds and, for the first time, provided evidence that contagious agalactia of sheep and goats occurs in Jordan.
\end{abstract}

Mycoplasma agalactiae, sheep, goats, Jordan, polymearase chain reaction

Contagious agalactia of sheep and goats is a serious infectious disease affecting small ruminants. It is characterised by arthritis, keratoconjunctivitis, pneumonia and, in females, mastitis and occasional abortion. It may be caused by any of the five mycoplasma species associated with this disease, namely, Mycoplasma agalactiae, Mycoplasma mycoides subsp. mycoides LC (large colony), Mycoplasma capricolum subsp. capricolum, Mycoplasma mycoides subsp. capri and Mycoplasma putrefaciens (Nicholas 1996; Sarris 1996; Bergonier et al. 1997; Bölske 1994). However, Mycoplasma agalactiae (M. agalactiae) is still regarded, particularly in sheep, as the "classical" aetiological agent of contagious agalactia (Bergonier et al. 1997). Mycoplasma putrefaciens is found only in goats. However, other animal species, such as cattle, camels or small wild ruminants, can also be infected (Perrin et al. 1994).

Contagious agalactia is at present an important disease in countries with intensive small animal husbandry, such as the Mediterranean region and the Balkan Peninsula, Western parts of Asia, and North, Central and East Africa (Gaillard-Perrin and Lenfant 1987; Garrido et al. 1987; Erdag 1989; Al-Zeftawi 1979; Belaid et al. 1990; Sarris 1996; Lambert 1987; Bergonier et al. 1997; Nicholas 1995; Da Massa et al. 1992; Damdinsuren 1989; Ismail 1993; Egwu et al. 1999; Kusiluka et al. 2000).

Although mortality from contagious agalactia in adult animals is not high, morbidity may be $30 \%$ to $60 \%$; but a serious disease in dams can often be associated with the death of their offspring ( $40 \%$ to $70 \%)$.

The economic impact of the disease lies in the decrease or loss of milk production and, less often, also in abortions in pregnant dams. In the countries where sheep and goat dairy products are important foods as well as commercial commodities, contagious agalactia is a serious problem in terms of veterinary health and socio-economic impacts (Nicholas 1998).

Address for correspondence:

Doc. MVDr. Dagmar Zendulková, CSc.

University of Veterinary and Pharmaceutical Sciences

Palackého 1-3, 61242 Brno

Czech Republic
Phone: +420541562306

Fax: +420549248841

E-mail: zendulkovad@vfu.cz

http://www.vfu.cz/acta-vet/actavet.htm 
Jordan is a country with intensive breeding of sheep and goats with a long-term tradition, but with little attention paid to the diagnosis of infectious agalactia. Unspecified health problems present in the herds of sheep and goats, which resulted in a decreased milk and meat yield, gave an impulse for this study.

\section{Material and Methods}

Animals examined

The animals used in the study came from the Al-Karak region of Jordan and included 15 Awassi sheep and 20 Baladi goats. Most animals showed clinical signs of disease. The clinical examination of sheep and goats, as well as sample collection was carried out by A. Madanat.

\section{Sample collection}

A total of 107 swabs were collected from nasal, conjunctival, vaginal or preputial mucosae and from the external auditory canal. The samples were immediately placed in test tubes with transport mycoplasma culture medium. This was supplemented with $1 \mathrm{mg}$ cefaperazone/ml medium (90\% cefaperazone sodium, Sigma, Aldrich Chemie $\mathrm{GmbH}$ ). Because deep-freezing facilities were not available in that part of Jordan, all collected samples were kept at $-20{ }^{\circ} \mathrm{C}$ until transported to the Czech Republic. All biological materials were transferred under the rules set by the State Veterinary Administration of the Czech Republic.

The samples were then examined and analysed at the Department of Infectious Diseases and Veterinary Epidemiology.

Culture techniques

The frozen samples were thawed and then grown in liquid and on solid (agar) mycoplasma culture media, as described by Hayflick (1956) and modified for the conditions of our laboratory. The examination also included cultivation of reference mycoplasma strains. The collected samples in transport culture medium were inoculated at $0.1-\mathrm{ml}$ amounts onto Petri dishes $(6 \mathrm{~cm}$ in diameter) with agar medium, and at $0.2-\mathrm{ml}$ amounts into test tubes with 2-ml liquid medium containing glucose. The solid media were incubated in a humid atmosphere of air with $5 \% \mathrm{CO}_{2}$ at $37{ }^{\circ} \mathrm{C}$. At 4-day intervals they were checked for the presence of mycoplasma colonies. The test tubes were incubated at $37{ }^{\circ} \mathrm{C}$ and examined every other day for a change in colour and turbidity of the medium. Positive cultures were frozen at $-80{ }^{\circ} \mathrm{C}$ until use, and those with no signs of growth, or change in colour or turbidity were excluded from the experiment at 21 days of incubation.

Identification of $M$. agalactiae by a polymerase chain reaction (PCR)

DNA was isolated from mycoplasma cells, using a QIAamp DNA mini-kit (QAIGEN, Germany). A 1-ml amount of mycoplasma culture in liquid medium with glucose was used for DNA purification in each isolated strain. Purified DNA was stored at $-80^{\circ} \mathrm{C}$ until use. Strain identification by PCR was carried out by the procedure described by Subramaniam et al. (1998) and modified to suit the conditions of our laboratory. For PCR assays, 50- $\mu \mathrm{l}$ volumes of reaction mixture were used. All reaction agents except primers were supplied by PROMEGA, USA. The primers used in the initial stage of examination were kindly donated by Professor Joachim Frey, University of Bern, Switzerland; afterwards, the primers were purchased from GENERI BIOTECH, Czech Republic. The primers and their sequences were as follows:

MAGAUVRC1-L 5' - CTC AAA AAT ACA TCA ACA AGC - 3'

MAGAUVRC1-R 5' - CTT CAA CTG ATG CAT CAT AA - 3'.

For each sample tested, $1 \mu \mathrm{l}$ isolated DNA obtained by purification was added to a reaction microtest tube containing $49 \mu \mathrm{l}$ master mix $(1 \mu \mathrm{l}$ of $10 \mathrm{mM}$ dNTP mix; $2 \mu \mathrm{l}$ of $25 \mathrm{mM} \mathrm{Mg} \mathrm{SO}$; $10 \mu \mathrm{l}$ of $5 \mathrm{X}$ PCR-buffer; $10 \mathrm{pmol} / \mu \mathrm{l}$ of each primer; $5 \mathrm{U}$ of Taq DNA polymerase/ml and PCR $\mathrm{H}_{2} \mathrm{O}$ ). Amplification of reaction mixtures was performed in a Progene TECHNE thermal cycler (England), with a heated lid, under the following conditions: - initial sample denaturation, $5 \mathrm{~min}$ at $95^{\circ} \mathrm{C}$

- 35 cycles: denaturation, $30 \mathrm{~s}$ at $94{ }^{\circ} \mathrm{C}$; annealing, $30 \mathrm{~s}$ at $50{ }^{\circ} \mathrm{C}$; extension, $1 \mathrm{~min}$ at $72{ }^{\circ} \mathrm{C}$

- completion of the amplification process by final extension at $72{ }^{\circ} \mathrm{C}$ for $10 \mathrm{~min}$.

The PCR products were run on a $1 \%$ agarose gel (AMRESCO, USA) in $1 \times$ Trisborate-EDTA electrophoresis buffer (40 min at $150 \mathrm{~V}$ ), stained with ethidium bromide, and visualized under UV. The fragment size specific for Mycoplasma agalactiae (1624 bp) was compared with the DNA ladder (O'GeneRulerTM DNA Ladder Mix, FERMENTAS, USA).

\section{Results}

Thirty-five Jordanian animals, 15 sheep and 20 goats, were examined and a total of 107 swab samples, 52 from sheep and 76 from goats, were collected for cultivation. Most animals had clinical signs suggesting the presence of contagious agalactia of sheep and goats. The swabs were taken from conjunctival, nasal, vaginal or preputial mucosae, and from the external auditory canal. 
Table 1. Examination of isolated strains by culture and PCR identification of M. agalactiae in sheep

\begin{tabular}{|l|l|c|r|r|r|r|r|r|}
\hline Species & Collection site & \multicolumn{2}{|c|}{ Solid medium } & \multicolumn{2}{c|}{ Liquid medium+glucose } & \multicolumn{2}{c|}{ PCR } \\
\hline \multirow{5}{*}{ Sheep } & & + & - & + & $+/-$ & - & + & - \\
\cline { 2 - 10 } & Conjunctiva & 7 & 6 & 5 & 2 & 6 & 2 & 11 \\
\cline { 2 - 10 } & Nose & 6 & 7 & 4 & 4 & 5 & 2 & 11 \\
\cline { 2 - 10 } & Vagina / Prepuce & 7 & 6 & 5 & 3 & 5 & 0 & 13 \\
\cline { 2 - 10 } & Auditory canal & 2 & 11 & 4 & 2 & 7 & 0 & 13 \\
\hline$\Sigma$ & 52 & 22 & 30 & 18 & 11 & 23 & 4 & 48 \\
\hline
\end{tabular}

Table 2. Examination of isolated strains by culture and PCR identification of M. agalactiae in goats

\begin{tabular}{|l|l|r|r|r|r|r|r|r|}
\hline Species & Collection site & \multicolumn{2}{|c|}{ Solid medium } & \multicolumn{2}{c|}{ Liquid medium + glucose } & \multicolumn{2}{c|}{ PCR } \\
\hline \multirow{5}{*}{ Goat } & & + & - & + & $+/-$ & - & + & - \\
\cline { 2 - 10 } & Conjunctiva & 10 & 9 & 6 & 4 & 9 & 3 & 16 \\
\cline { 2 - 10 } & Nose & 7 & 12 & 4 & 4 & 11 & 3 & 16 \\
\cline { 2 - 10 } & Vagina / Prepuce & 9 & 10 & 4 & 5 & 10 & 2 & 17 \\
\cline { 2 - 10 } & Auditory canal & 9 & 10 & 2 & 5 & 12 & 9 & 10 \\
\hline$\Sigma$ & 76 & 35 & 41 & 16 & 18 & 42 & 17 & 59 \\
\hline
\end{tabular}

The results of cultivation in liquid and on solid media and the identification of strains are presented in Tables 1 and 2. Nine isolates showed "film and spots" production. This phenomenon often indicates the presence of $M$. agalactiae in culture, but may also be associated with some bovine species. The growth of mycoplasmas in liquid media with glucose was demonstrated by a change in colour due to biochemical activity of the microorganisms. The isolated strains were then examined by PCR. (Plate III, Fig. 1).

In sheep, the highest number of strains on solid medium was obtained from swabs collected from the conjunctiva and vagina, with seven strains being isolated from each (i.e. $13.4 \%$ of the total number of ovine samples). On the other hand, only two strains (3.8\%) were isolated from the swabs taken from the external auditory canal. Examination of 52 swab samples by culture on solid medium provided 22 mycoplasma strains $(42.3 \%)$.

In liquid media, swabs from the conjunctival and vaginal mucosae each yielded five strains (9.6\%) and those from the nasal mucosa and external auditory canal each provided four $(7.6 \%)$ strains. The total number of mycoplasma strains isolated in liquid medium was 18 (i.e., $34.4 \%$ of the total number of ovine samples).

PCR identification of M. agalactiae was successful in two strains isolated from nasal swabs and in two from conjunctival swabs. This was proof that four (26.6\%) sheep out of 15 were infected with M. agalactiae.

On solid media, the highest number of isolated strains was obtained from conjunctival swabs $(10 ; 13.1 \%)$ and the lowest from nasal swabs $(7 ; 9.9 \%)$. A total of 35 mycoplasma strains were isolated (i.e., $46.1 \%$ of all caprine swabs).

In liquid media, conjunctiva swabs also gave the highest number of strains $(6 ; 7.9 \%)$, while only two strains $(2.9 \%)$ were obtained from the external auditory canal. Examination by culture in liquid media showed $16(21.9 \%)$ strains.

The PCR technique showed that $17(85.0 \%)$ out of 20 goats examined were positive for M. agalactiae. Nine strains (11.8\%) came from the external auditory canal because, in goats, all swabs collected from that site were examined by PCR.

As only four sheep tested positive for M. agalactiae by PCR, it implies that the prevalence of $M$. agalactiae was three-times higher in goats than in sheep (85\% and $36.6 \%$, respectively). 


\section{Discussion}

The primary diagnosis of contagious agalactia of sheep and goats can be made on the basis of clinical signs together with epidemiological data available. It is relatively easy if all three clinical symptoms, i.e., mastitis with milk loss, keratoconjunctivitis and arthritis, are observed in the herd at the same time. A less severe disease with the absence of arthritis and keratoconjunctivitis is usually found in endemic areas. It is manifested as mastitis of lactating dams which develops shortly after parturition.

The clinical diagnosis should always be confirmed by laboratory examination, including identification of the mycoplasma species causing the infection. From the classical laboratory methods for $M$. agalactiae identification, Hayflick's culture technique is used most frequently.

During cultivation of swabs in liquid medium with glucose, the presence of $M$. agalactiae was indicated by a change in colour. However, this change caused by a $\mathrm{pH}$ decrease is not due to fermentation of glucose as in other mycoplasma species (M. capricolum subsp. capricolum, M. mycoides subsp. mycoides LC, M. ovipneumoniae, M. putrefaciens), but because of slight production of acidic products by the metabolism of compounds other than glucose (Goll 1994). The presence or absence of colour change cannot be considered as a reliable result for diagnostic purposes, because liquid media with glucose are not always acidified by growing $M$. agalactiae cells. If the results are dubious, it is necessary to inoculate solid medium with this culture and evaluate the growth of colonies.

A characteristic feature of the presence of $M$. agalactiae, as well as some bovine mycoplasmas such as $M$. bovis or M. bovigenitalium, is the "film and spots" phenomenon. This is observed on solid media containing $20 \%$ heat-inactivated equine serum. A wrinkled film on the medium surface is composed of cholesterol and phospholipids; tiny black spots appearing below and around colonies are attributed to the deposition of calcium and magnesium salts of fatty acids released by lipolytic activity of mycoplasma cells (Fre undt 1983). However, an incubation period exceeding 14 days may result in a false positive reaction.

A routine identification of mycoplasma species is usually based on classical methods, i.e., biochemical tests and immunofluorescence examination. These methods are timeconsuming and their results are sometimes difficult to interpret (Lambert 1987; Le Goff a Perreau, 1984; Tsaknakis et al. 1992), which makes identification of the examined species a problem. There is still an absence of standard reference tests that would enable us to compare the results from different laboratories (Lambert 1987; Nicholas et Bashirudin 1995; Bergonier et al. 1997; Ruffin 2001). However, mycoplasma infection in a herd usually spreads rapidly, and therefore it is important to have reliable results as early as possible.

Today, molecular biology methods seem very promising. They can speed up laboratory diagnostic procedures and make them more accurate. One of the options is the use of genetic probes complementary to chromosomal DNA or 16S RNA segments (Matts on et al. 1991; Dedieu et al. 1992; Tola et al. 1994). Although the specificity of this technique is high and DNA probes mean a considerable advance in the diagnosis of mycoplasma infections, efforts in research have recently aimed at the development of PCR techniques which are much more sensitive (Dedieu et al. 1995; Tola et al. 1996 a,b; Tola et al. 1997; Bergonier et al. 1996; Chavez et al. 1995; Subramaniam et al. 1998; Greco et al. 2001). So far, however, no standard PCR procedures effective for routine diagnosis have been available (Bashirudin et al. 2004).

From the broad range of PCR techniques currently used, we employed the procedure developed by Subramaniam et al. (1998), because it is considered to be very reliable and has a chance to become a candidate for the selection of a reference test in the future 
(Bashirudin et al. 2004). The method did prove effective for identification of $M$. agalactiae strains in the Jordanian sheep and goat herds examined in this study.

The highest numbers of strains were isolated from conjunctival swabs in both sheep and goats, then from vaginal and nasal mucosa samples in sheep and from the external auditory canal in goats. The collection sites were chosen in accordance with those preferred by other authors (Rosendal 1994; Da Massa 1996). Some authors recommend to collect also samples of milk secretion; because numbers of mycoplasmas in it may vary considerably, it is necessary to repeat the sampling several times (Rosendal 1994). Since repeated collections were not possible for technical reasons, we did not include this material in our examination. Specimens can also be taken from tonsillar crypts. This technique, however, requires sedation of animals, which is costly and also burdensome for the animal. Isolation of $M$. agalactiae from blood samples is used rarely, because the method is not effective and is suitable only for the early, acute stage of the disease.

We did not expect to obtain so many positive results from external auditory canal swabs in goats. This unusual collection site was described recently, and proved suitable for diagnostic purposes in goats (Da Massa and Brooks 1991; Da Massa 1996). Since mycoplasmas are detected in the external auditory canals together with ear mites (Raillietia caprae in particular) some authors suggest that the mites have a role of passive vectors and, in the herd, transfer mycoplasmas from infected to healthy animals. It is most probable that mycoplasmas are not present in the auditory canals of healthy animals (D a Mas sa 1996).

Since contagious agalactia presents a significant animal health problem in the Arab countries, we had generally expected more $M$. agalactiae isolations from all examined samples in the laboratory than we achieved. We suggest that, among other things, this was due to the fact that the samples were collected during a hot summer period and, for technical reasons, immediate deep freezing was not possible; nor was it feasible to keep the samples permanently frozen during transportation to the Czech Republic. We were aware of the recommendations for international transport of microbiological specimens suggesting lyophilisation for materials that cannot be kept frozen, but this method of preservation was unattainable under the conditions available in Jordan.

\section{Průkaz Mycoplasma agalactiae v jordánských chovech ovcí a koz pomocí polymerázové řetězové reakce}

Cílem předkládané práce bylo zjistit, zda ovce a kozy z vybraných jordánských chovů jsou infikovány Mycoplasma agalactiae - nejčastějším původcem nakažlivé agalakcie ovcí a koz. Všechna sledovaná zvířata vykazovala v době odběru vzorků klinické příznaky onemocnění. Soubor zahrnoval celkem 35 zvírat, z toho 15 ovcí a 20 koz. Za účelem mikrobiologického vyšetření od nich bylo odebráno celkem 107 výtěrů (ze sliznice spojivkové, nosní, vaginální či prepuciální a ze zevního zvukovodu). K identifikaci izolovaných druhů byla použita polymerázová řetězová reakce. Z 35 vyšetřovaných zvířat se touto metodou podařilo prokázat 21 pozitivních jedinců (4 ovce a $17 \mathrm{koz}$ ). Tím byl potvrzen náš předpoklad výskytu Mycoplasma agalactiae v jordánských chovech. Jedná se současně o první průkaz nakažlivé agalakcie ovcí a koz na tomto území.

\section{Acknowledgement}

This study was supported by funds from the MSM 6215712403 and EU COST 826.10 projects.

\section{References}

AL-ZEFTAWI NMN 1979: The role of Mycoplasmatales in diseases of sheep and goats in Egypt. PhD. Thesis, Univ of Cairo, Cairo, $180 \mathrm{p}$.

BASHIRUDIN JB, FREY J, KÖNIGSSON MH, JOHANSSON K-E, HOTZEL H, DILLER R, DE SANTIS P, BOTELHO A, AYLING RD, NICHOLAS RAJ, THIACOURT F, SACHSE K 2004: Evaluation of PCR systems 
for the identification and differentiation of Mycoplasma agalactiae and Mycoplasma bovis: A collaborative trial. Vet J 169: 268 - 275

BELAID B, LE GOFF C, LEFÉVRE PC 1990: Enquete épidémiologique et sérodiagnostic de l'agalactie contagieuse des petits ruminants de l'Est algérien Rev Elev Med Vet Pays Trop 43: 37 - 41

BERGONIER D, DE SIMONE F, RUSSO P, SOLSONA M, LAMBERT M, POUMARAT F 1996: Variable expression and geographic distribution of Mycoplasma agalactiae surface epitopes demonstrated with monoclonal antibodies. FEMS Microbiol Letters 143: 159 - 165

BERGONIER D, BERTHELOT X, POUMARAT F 1997: Contagious agalactia of small ruminants: current knowledge concerning epidemiology, diagnosis and control. Rev Sci Tech OIE 16: 848 - 873

BÖLSKE G, WILHEMSSON E, TWINAMASIKO E, JOHANSSON K-E 1994: Detection of Mycoplasma capricolum subsp. capripneumoniae in goats and sheep in Uganda. IOM Letters 3: 19 - 20

CHAVEZ GONZALES YR, BASCUNANA CR, BÖLSKE G, MATTSSON JG, FERNANDEZ MOLINA CF, JOHANSSON K-E 1995: In vitro amplification of the 16S rRNA genes from Mycoplasma bovis and Mycoplasma agalactiae by PCR. Vet Microbiol 47: 183 - 190

DA MASSA AJ 1996: Mycoplasma infections of goats and sheep. In: Tully, JG and Razin S (Eds): Molecular and diagnostic procedures in mycoplasmology. Vol II. Academic Press, San Diego, 265 - 273

DA MASSA AJ, BROOKS DL 1991: The external ear canal of goats and other animals as a Mycoplasma habitat. Small Ruminant Res 4: 85 - 93

DA MASSA AJ, WAKENELL PS, BROOKS DL 1992: Mycoplasmas of goats and sheep. J Vet Diagn Invest 4: 101 - 113

DAMDINSUREN Ch 1989: Mycoplasmosis in farm animals in Mongolia: Immunization of sheep and goats against contagious agalactia. Arch Exp VetMed 43: 769 - 772

DEDIEU LA, MADY V, LEFEVRE PC 1992: Development of a species - specific DNA probe for Mycoplasma capricolum. Vet Microbiol 32: 189 - 197

DEDIEU LA, MADY V, LEFEVRE PC 1995: Development of two PCR assays for the identification of mycoplasmas causing contagious agalactia. FEMS Letters 129: 243 - 250

EGWU GO, AMEH JA, ALIU MM, MOHAMMED FD 1999: Caprine mycoplasmal mastitis in Nigeria. Veterinarski Arhiv 69: 241 - 250

ERDAG O 1989: Investigations on the preparation and application of vaccine against contagious Mycoplasma agalactiae or sheep and goats in Turkey. Proc Int Symp Mycoplasma. Theiler, pp. 20 - 22

FREUNDT EA 1983: Film and spot production. In: RAZIN, S and TULLY, JG (Eds). Methods in Mycoplasmology, Vol. I, Academic Press, New York, pp. 373 - 374

GAILLARD - PERRIN G, LENFANT D 1987: The importance of Mycoplasma mycoides subsp. mycoides in caprine mammary disease in France. In: Jones, GE (Ed.): Agriculture: Contagious Agalactia and Other Mycoplasmal Diseases of Small Ruminants. European Communities, Luxembourg, pp. 59 - 69

GARRIDO F, LEÓN L, LADERO JL, CUELLAR L, DIAZ MA 1987: Contagious agalactia in Spain. In: Jones, GE (Ed.): Agriculture: Contagious Agalactia and Other Mycoplasmal Diseases of Small Ruminants. European Communities, Luxembourg, pp. 1- 5

GRECO G, CORRENTE M, MARTELLA V, PRATELLI A, BUONAVOGLIA D 2001: A multiplex - PCR for the diagnosis of contagious agalactia of sheep and goats. Mol Cell Probes 15: 21 - 25

GOLL F Jr 1994: Identification of mycoplasmas isolated from domestic animals. In: Whitford, HW, Rosenbush, RF, Lauerman, LH (Eds): Mycoplasmosis in Animals: Laboratory Diagnosis. Iowa State University Press, Ames, pp. 15 - 30

ISMAIL SF 1993: Infectious caprine keratokonjunctivitis. Assiut Vet Med J 28: 264 - 271

KOPPEL Z 1982: Infekčná agalakcia ovcí a koz. In: Hejlíček, K, Vrtiak, JO a kol.: Speciální epizootologie 1. SZN, Praha, pp. 242 - 246

KUSILUKA LJM, OJENIYI B, FRIIS NF, KAZWALA RR, KOKOTOVIC B 2000: Mycoplasmas isolated from the respiratory tract of cattle and goats in Tanzania. Acta Vet Scand 41: 299 - 309

LAMBERT M 1987: Contagious agalactia of sheep and goats. In: Mycoplasmoses of ruminants. Rev Sci Tech OIE 6: $699-711$

LE GOFF C, PERREAU P 1984: Possibilities and limitations of serological diagnosis in contagious agalactia of small ruminants. In: Yvore, P and Perrin, G (Ed).: Les maladies de la chevre. Niort, France, 9 - 11 October. Les colloques de l'Institut National de la Recherche Agronomique, Paris, pp. 271 - 278

MATTSON JG, GERSDORF H, GOBEL UB, JOHANSSON K-E 1991: Detection of Mycoplasma bovis and Mycoplasma agalactiae by oligonucleotide probes complementary to 16S rRNA. Mol Cell Probes 5: 27 - 35

NICHOLAS R 1996: Contagious agalactia: an update. In: Frey, J and Sarris, K: COST 826 Agriculture and Biotechnology, "Mycoplasmas of Ruminants: Pathogenicity, Diagnostics, Epidemiology and Molecular Genetics," EUR 16934 Luxembourg, 172 p.

NICHOLAS R 1995: Contagious agalactia. State Vet J 5: 13 - 15

NICHOLAS R 1998: The veterinary signifikance of mycoplasmas. In: Miles, R and Nicholas, R (Ed.): Mycoplasma protocols, Humana Press, Totowa, pp. 17 - 24

NICHOLAS R, BASHIRUDIN JB 1995: Mycoplasma mycoides subspecies mycoides (small colony variant): The agent of contagious bovine pleuropneumonia and member of the "mycoplasma mycoides cluster." J Comp Path 113: 1 - 27 
PERRIN J, MÜLLER M, ZANGGER N, NICOLET J 1994: Infection a Mycoplasma mycoides subsp. mycoides $L C$ chez des cabris bézoard (Capra aegagrus cretica) au jardin zoologique de Berne. Schweizer Arch Tierheilk 136: $270-274$

ROSENDAL S 1994: Ovine and caprine mycoplasmas. In: Whitford, HW, Rosenbush, RF, Lauerman, LH (Eds): Mycoplasmosis in Animals: Laboratory Diagnosis. Iowa State University Press, Ames, pp. 84 - 96

ROSS RF 1993: Mycoplasma - animal pathogen. In: Kahane, I and Adoni, A: Rapid diagnosis of mycoplasmas. FEMS Symposium No. 62. Plenum Press, New York and London, pp. 69 - 109

RUFFIN DC 2001: Mycoplasma infections in small ruminants. Vet Clin North Am 17: 315 - 332

SARRIS K 1996: Contagious agalactia. In: Frey, J. and Sarris, K.: Mycoplasmas of ruminants: pathogenicity, diagnostics, epidemiology and molecular genetics, COST 826, EUR 16934, European Commission, European Communities Official Publications Office, Luxembourg, pp. 12 -15

SUBRAMANIAM S, BERGONIER D, POUMARAT F, CAPAUL S, SCHLÄTTER Y, NICOLET J, FREY J 1998: Species identification of Mycoplasma bovis and Mycoplasma agalactiae based on the uvrC genes by PCR. Mol Cel Probes 12: 161 - 169

TOLA S, IDINI G, MANUNTA D, CASCIANO IG, ROCCHIGIANI AM, ANGIOI A, LEORI G 1996a: Comparison of Mycoplasma agalactiae isolates by pulsed field gel electrophoresis, SDS - PAGE and immunoblotting. FEMS Microbiol Letters 143: 259 - 265

TOLA S, IDINI G, MANUNTA D, GALLERI G, ANGIOI A, ROCCHIGIANI AM, LEORI G 1996b: Rapid and specific detection of Mycoplasma agalactiae by polymerase chain reaction. Vet Microbiol 51: 77 - 84

TOLA S, ANGIOI A, ROCCHIGIANI AM, IDINI G, MANUNTA D, GALLERI G, LEORI G 1997: Detection of Mycoplasma agalactiae in sheep milk samples by polymerase chain reaction. Vet Microbiol 54: 17 - 22

TOLA S, RIZZU P LEORI G 1994: A species-specific DNA probe for the detection of Mycoplasma agalactiae. Vet. Microbiol 41: 355 - 361

TSAKNAKIS I, KNOTOS P, MPOUPTZE E, MEGA A, SARRIS K 1992: Epidemiological studies on contagious agalactia in sheep and goats in Chalkidiki, northern Greece. Bull Hellenic vet med Soc 43: 250 - 254 
Zendulková D. et al.: Detection of Mycoplasma ... pp. 71-77

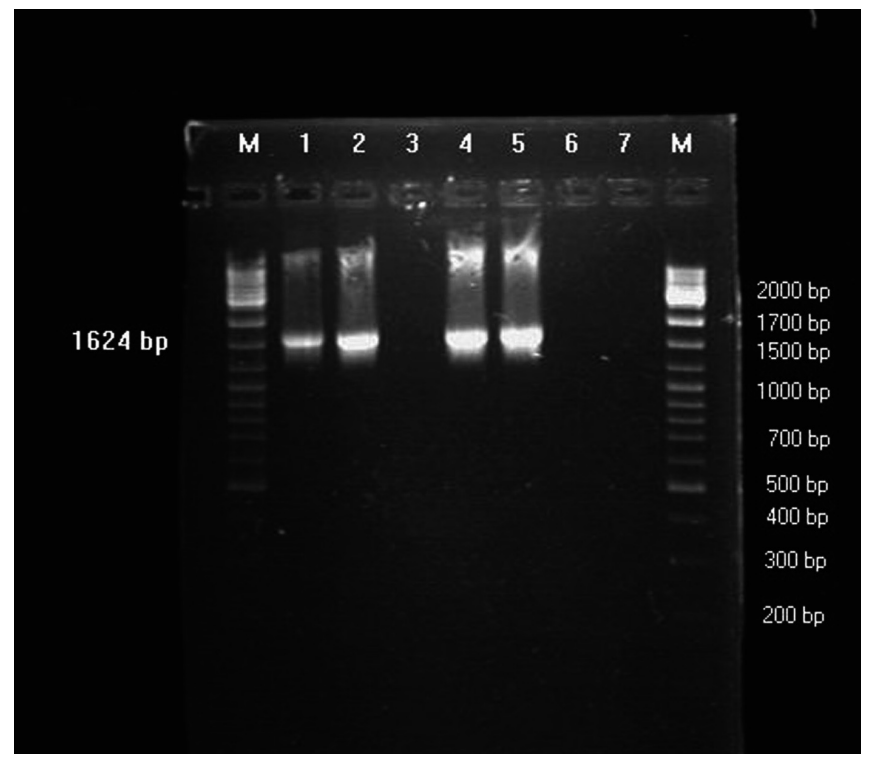

Fig. 1: Identification of the isolated $M$. agalactiae strains by PCR

1 - M. agalactiae - PG 2 type strain (positive control)

2 - M. agalactiae - Jordanian positive strain (goat, external auditory canal)

3 - M. agalactiae - Jordanian negative strain (sheep, vaginal mucosa)

4 - M. agalactiae - Jordanian positive strain (goat, vaginal mucosa)

5 - M. agalactiae - Jordanian positive strain (sheep, conjuctival mucosa)

6 - M. agalactiae - Jordanian negative strain (goat, nose mucosa)

7 - negative control

M - DNA ladder (marker) 